\title{
Tracing the Notion of Rural Environmental Development Concept by M. Saleh Lahade, South Sulawesi in 1950s
}

\author{
La Malihu*, Yety Rochwulaningsih 'Dhanang Respati Puguh \\ Department of History, Faculty of Humanities, Diponegoro University, Semarang-Indonesia
}

\begin{abstract}
This paper aims to trace M. Saleh Lahade's notion on the concept of rural development in South Sulawesi in the 1950s. Used historical method which includes several phases, namely: heuristics, criticism, interpretation and historiography. The result reveals the fact that M. Saleh Lahade's ideas were based on the physical environment and severe human settlement were damaged, the stagnation of the economy and the occurrence of stagnation in social life as a result of prolonged armed conflict. The concepts offered are based on falsafah and local wisdom that has long been developed, such as the spirit to act when finding something that is broken, the spirit of never giving up, the spirit of honesty, the spirit of independence (to maradeka), and the spirit of building harmony in people's lives. To develop his ideas M. Saleh Lahade used the concept of cluster units. Through this approach, rural service units are built in one mini cluster to create effectiveness and efficiency in public services. In addition, it also encourages the creation of a better physical and social environment, a more secure public health, and faster economic wheels.
\end{abstract}

Keywords: M. Saleh Lahade; Environmental Development Concept; South Sulawesi.

\section{Introduction}

During the 1950s until the early 1960s, South Sulawesi continued to be plagued by armed conflict. A number of rebellions occurred, including the Andi Aziz prising (May 1950), the DI / TII Uprising Kahar Muzakkar (1953-1965), and the Permesta Uprising (1957-1961). Among the three rebellions, the biggest impact on the lives of rural communities was the DI / TII uprising Kahar Muzakkar. Apart from the relatively long time span, DI / TII also controlled a very large area and covered most rural areas.[1] This is inseparable from the charisma Kahar Muzakkar and the narrative of the struggle carried out, namely to establish an Islamic state and enforce Islamic low[2], which of course has its own appeal for some people of South Sulawesi. As a result of the DI / TII rebellion, the South Sulawesi region was practically divided into two areas of influence, namely the territory of the Republic of

* Corresponding author: lamalihu2020@gmail.com 
Indonesia which controlled urban areas and the DI / TII region which controlled most of the rural areas [3].The protracted conflict between the two forces has caused uncertainty in people's lives. The wheels of the economy were stagnant, settlements burned and many public facilities were destroyed, the natural environment was damaged and not maintained, so that people's lives became increasingly difficult. According to M. Saleh Lahade, from around 47,500 villages registered in the State Planning Bureau, around 3000 villages are located in South \& Southeast Sulawesi. And out of 3000 villages around $60 \%$ have been burnt down and the inhabitants left the place to a new place: some went to the forest and set up "to romang I to ale" villages, some fled near army posts, to big cities, and others cross the seas to Central Sulawesi, Kalimantan, Nusa Tenggara, Java and Sumatra [4].

M. Saleh Lahade notes that from 1900 to 1957 the people of South Sulawesi had never experienced absolute calm. Since then there have been a series of upheaval and chaos that have continued. Starting with the king's resistance against the Dutch; the days of thieves / pagorra; the time of the Heren-Dienst; Malaise era; Japanese era (romusha), the Westerling massacre, and finally the armed conflict between the TNI versus DI / TII.

The series of events has damaged the joints of people's lives, especially rural communities. According to M. Saleh Lahade such conditions should not be allowed and this is considered as one of the heroes of the revolution that must be resolved immediately. But careful planning is needed to rebuild the damaged rural environment. Based on his experience as a soldier during the war for independence, he was well aware of how much the contribution of rural communities to the struggle for independence. Therefore it is necessary to immediately rebuild the damaged rural environment so that it becomes a developed and modern village. Thus the village will remain a pillar of the nation's strength and continue to contribute to the struggle for independence and state sovereignty in the future.

This paper will try to trace how M. Saleh Lahade's ideas about the concept of rural environment development to become a modern village.

\section{Method}

The method used in writing this paper is a historical method[5] that includes 4 stages, namely: (1) heuristics, (2) criticism, (3) interpretation, and (4) historiography. Written data in the form of data archive which is the mainstay of this paper was collected at the Office of the Library and Archives Office of the South Sulawesi Province in Makassar, especially the private archive collection of M. Saleh Lahade. To support archived data, a number of articles and books have also been used. To guarantee the accuracy of the data, the data is verified through criticism, both internal and external. Through verification found historical facts which are then sorted and grouped to find causal relationships and meanings between facts. These facts are then arranged into writing as set out in this paper.

\section{Results and Discussion}

\subsection{Saleh Lahade in Career and Controversy}

M. Saleh Lahade was a military officer with the rank of Lieutenant Colonel who had long served in the Wirabuana VII Army and Territorial Headquarters in the 1950s. His career in the military was quite brilliant and was an accomplished drafter so he was often trusted to appear as a speaker at various local and national level meetings. He was also assigned several 
times as an officer who was seconded to official duties outside the military. That way M. Saleh Lahade actually has better career opportunities for the long term.

He was born in Camba, Maros, on April 20, 1920 to a Bugis aristocratic family. As a noble child, after his basic education he was accepted into MULO (Makassar), AMS (Jakarta), MLS (Bogor), and finally completed his education at Noogya-Tjun-Gakko, Bogor, in 1943[6]. As a highly educated person, especially in agriculture, M. Saleh Lahade can actually work directly in the agricultural sector. However, he prefers to engage in underground movements against Japan. After the proclamation of independence he entered the military service as a member of the TNI and was involved in several military operations in Central and East Java. After the recognition of sovereignty, by Mabesad, he was assigned to Makassar as a staff officer at the Wirabuana VII Army and Territorial Command Headquarters. He then helped quell the Andi Aziz rebellion, RMS, and DI / TII. But in 1957 there was irony. He took a "controversial" step by becoming involved in the Permesta Movement[7] and even became one of his central figures with Ventje Sumual.

Regarding his involvement in the Permesta Movement, he wrote:

"If it were only involved with the Permesta Movement and PRRI in 1957 - 1958, then at that time it was realized, to the utmost, that only betting all ranks and signs of service were only obtained from the Republic of Indonesia. Basically, they also joined the TNI as patriots and not as army troops. Discipline alone is the discipline of life, the meaning of discipline which is more subject to the call of the national revolution, to the interests and safety of the people of Indonesia and the Unitary State of the Republic of Indonesia.'[8]

As a result of his involvement, M. Saleh Lahade was forced to end his military career. He was arrested and sent to prison for 4 years (1958-1962). He was only released in 1963 after receiving an amnesty from President Sukarno.[9]

\subsection{Building a Village Based on Local Wisdom}

The village is a settlement agglomeration consisting of several small settlement units which are usually known as villages. The village is also an administrative area unit under the subdistrict led by the Village Head. Village locations are usually outside urban areas.

Mudrajat Kuncoro, divides the rural environment into three categories in regional development planning, namely the physical environment, the regulatory environment and the behavioral environment[10]. The physical environment aspect will be the main focus in this article because this is the main focus of the conception of rural development that was conceived by M. Saleh Lahade.

In consideration of Law No. 6 of 2014 concerning Villages it is said that "villages have original rights and traditional rights in regulating and managing the interests of local communities"[11]. What is stipulated in the Village Law has been thought by M. Saleh Lahade. In composing the concept of rural development, M. Saleh Lahade refers a lot to the spirit and philosophy of life that has long existed and developed in society. First, the spirit and philosophy contained in La Towa, a famous classic book in the Bugis-Makassar society. There is a long-held norm that "whoever sees the way to goodness (improvement, modern progress), it is he who must tell it to others." This is the spirit that pushed M. Saleh Lahade to design the concept of rural development as a calling when he saw massive damage due to a prolonged armed conflict.

Second, the unyielding spirit of executing a program. For this reason he chose the nautical spirit in one of the Kelong Mangkasara which reads:

"Biar dihantam angin barat 


\author{
Biar dihempas ombak dan gelombang \\ Meski kemudi itu patah \\ Meski layar itu robek \\ Sekalipun tali jangkar putus \\ Namun adat itu tetap benar"'[12]
}

With the spirit of never giving up, whatever happens and with any limitations, rural development must go on. You do this by utilizing all the potential and available village resources to the maximum and foster a spirit of mutual cooperation. Third, honesty, in what is now known as accountability. According to M. Saleh Lahade there must be honesty in the implementation of village development. There are a number of honesty values that he learned from Kajao Lalido's thoughts that need to be instilled in the community to strengthen their character, namely: Don't take things (possessions) that are not your damage (yours) ; Don't take buffalo that isn't your buffalo; Do not take wood, which has been cut into pieces, if not you cut it; Because, if this happens, the enemy is easy to enter the country and difficult to be driven out.

Fourth, the principle of "to maradeka" which in Sukarno's term self-help and in terms of what is now known as independence. According to Saleh Lahade, the characteristics of free people is always trying to overcome problems on the basis of their own abilities and strengths (self-help). Do not like to stand by and wait for pakkamase (gifts) from others. But this "to maradeka" principle does not deny the principle of help or mutual cooperation, known as "Siturungi". The principle of kegotongroyongan is used in doing large works or joint celebrations, such as building houses, making equipment, events of death, Islamization, circumcision and so on.

Fifth, build harmony in social relationships. Harmony becomes an important part in the development of rural communities. For this reason, there are principles of respect and respect for fellow villagers. In the community structure there are already elements that are highly respected, namely: (1) Head / Anrong Tau; (2) Parents; (3) Teachers (school teachers and religious teachers); (4) Imam / Kadhi; (5) People of royal descent. These elements become the most important patrons in building community character and obedience. They are not only respected, but also obeyed and imitated by the entire population, because of the height of character and character.

Based on the description above, it is clear that the conception of rural community development offered by M. Saleh Lahade, besides covering outward elements, also includes inner and spiritual elements. This is what is used as a foundation in the preparation of the concept of rural environment development.

\title{
3.3 Development of Cluster Unit-Based Rural Environments
}

The concept of village autonomy has long been conceived by M. Saleh Lahade, which he termed modern village autonomy. Village autonomy is an instrument of village development that enables village community leaders to provide free guidance in managing village households and allows village rights and obligations to be given. At the very least, what was owned by the village which until then was still protected by colonial law must be maintained. In order for the implementation of village autonomy to touch more on the real essence and be more democratic, then village autonomy must begin with the direct election of village heads by the village community. In line with that, there must also be a special budget allocation for villages that is given regularly and continuously. Without village autonomy and without a special budget for the village, any program to be implemented in village development will be in vain. 
After the issue of village head election and the allocation of special budget for the village, the next urgent matter that needs to be regulated in village development is the agrarian problem. The agrarian problem is a hung problem and is a legacy from the colonial period. And this according to M. Saleh Lahade is one of the heroes of the revolution that must be completed. The reorganization must be oriented to the interests of rural communities with an emphasis on the aspect of equitable redistribution of land use rights. As long as there is still vacant land, no more mature residents should be classified as possessing people. All rights related to diagramming like ownership rights, borrowing rights, leasing rights and working rights must be clearly regulated by law. Also the status of ornamental / kalompoang lands and pangareang / akkenanreang lands, "cost" lands, must also be determined by law so that an autonomous village knows clearly what its possessions are the source of village wealth. With such an arrangement, the chartered sector also determines the annual village budget.

The development of facilities and infrastructure relating to public services and the acceleration of the economy in the rural environment needs to be regulated based on a cluster unit approach where in a village environment there are integrated and integrated service units in one system. The cluster unit approach is believed to create faster and more efficient public services. The following notes regarding the conception of rural environment development are based on the objectives delivered by M. Saleh Lahade at a Congress held by Permesta on 7 December 1957[13].

The purpose of the cluster unit concept is to create efficiency and effectiveness in public services. For this reason, village halls must be built in twins or side by side with offices and homes of village heads and village officials. With this concept, there are two conveniences that can be obtained at once. First, savings in transportation costs and travel time for Village Heads and Village Administrators to the office where they work. Second, the community will always be served because the Village Head and Village Administrator will always be in place.

Furthermore, public schools were built side by side with the homes of teachers and school principals. That is, the school and the residence of the teacher and principal become a separate cluster unit in a rural area. This concept is intended to facilitate services in the education sector. Teachers and school principals can carry out their duties and service functions optimally because their attendance to school becomes easier. Their presence is no longer constrained by distance or the condition of road infrastructure and weather, especially during the rainy season. They can reach schools more easily at any time and in any situation.

Furthermore, the mosque must be built in a twin with the mosque where the children recite, with the requirements office / NTR, with the imam / kadhi house and if necessary a place that regulates waqf, baitulmal, zakat and fitrah which is also built side by side in the same place. This concept will give birth to an integrated cluster of religious services that are in a separate unit in a rural environment. These support units will work and work together as a system to support the religious activities of rural communities. It is in this cluster unit that humanitarian services are organized such as helping the needy and the disabled, including helping Islamic boarding schools and madrassas organize waqf, baitulmal, zakat and fitrah.

To support the rotation of the economy, it is necessary to build twin markets with cooperative offices and village granaries with twin village banks. Markets, cooperatives, granaries and village banks are all seen as pillars of the village economy. As infrastructure to support the smooth rotation of the economic wheels, then in the village environment it is necessary to build village roads, bridges, waterways and dams. In addition, it is necessary to mobilize agriculture with more modern methods, animal husbandry and fisheries, revitalize the industry and craft sector, encourage trade, develop village forests and reforest, provide electricity, provide small rice mill services, and open relations with other villages.

Related to the health sector, the Polyclinic and BKAI must be built twin with housing for paramedics and midwives. In addition it also needs to be accompanied by a house and yard maintenance program, a place to defecate, a place for animal enclosures, setting the fence of 
the house and garden fence, providing healthy food, eradicating flies and mosquitoes, eradicating infectious diseases. Also in each village there must be a large field for sports and other social activities.

Regarding the development of human resources, routine activities must be raised in each village, especially: (1) religious study and illumination, (2) general knowledge, (3) illiteracy eradication, (4) reading gardens, (5) reading Lontara and staging art, (6) providing capable teaching staff to teach in schools. In addition, it is necessary to turn on courses, such as encouraging cadre courses, literacy courses, religious and traditional leaders courses, hygiene, health and sports counseling courses. In addition, training needs to be held for village and religious teachers; Agricultural, fishery, and animal cadre training; and cadre training exercises.

As an initial step in the implementation of the village development concept, M. Saleh Lahade suggested that the implementation begin in areas that are considered to be more conducive, such as Gowa along the Makassar-Malino road, Makassar along the MakassarMandale road, All of Parepare Regency, all of Wajo, the whole of Soppeng, Muna and Buton Islands in Southeast Sulawesi, and Selayar and Bantaeng Islands. The regions mentioned above are welcome to design village development concepts whose designs are left to the local people.

\section{Conclusion}

The village autonomy that has been revised today has apparently been conceived by M. Saleh Lahade since 1957. Likewise, the practice of direct selection of village heads by villagers and village funding. The aspect that is not yet implemented is the integration of work units into one cluster in an integrated manner. Whereas with this cluster system, public services can be more effective and efficient.

\section{Acknowledgements}

This manuscript is a part of doctoral dissertation research which has been supported by Directorate of Community Service Research (DPRM).

\section{References}

1. Anhar Gonggong, Abdul Qahhar Mudzakkar : Dari Patriot Hingga Pemberontak, 4041, (2004).

2. C. Van Dijk, Darul Islam: Sebuah Pemberontakan, 179-181 (1993).

3. Esther Velthoen, "Memetakan Sulawesi Tahun 1950-an" in Sita Van Bemmelen \& Remco Raben, Antara Daerah dan Negara: Indonesia Tahun 1950-an, 197, (2011).

4. M. Saleh Lahade, Realisasi Pembangunan Masyarakat Desa Moderen (a special speech delivered at the PERMESTAS Congress, 4 (1957)

5. Kuntowijoyo, Pengantar Ilmu Sejarah, 94-103 (1999).

6. M. Saleh Lahade "Curriculum Vitae", Collection of M. Saleh Lahade Archives No.19, the South Sulawesi Provincial Library and Archives Board, (1971).

7. Ventje HN Sumual, Memoar, 229, (2011). 
8. Curriculum Vitae of M. Saleh Lahade (specifically written as a condition for registering to become a candidate for the DPR-RI member of the Work Group in the 1971 Election), in the collection of M. Saleh Lahade Archives No.19, the South Sulawesi Provincial Library and Archives Board, (1971).

9. RZ Leirissa, PRRI PERMESTA: Strategi Membangun Indonesia Tanpa Komunis, 212, 222, (1991)

10. Mudrajat Kuncoro, 2018, Perencanaan Pembangunan Daerah: Teori dan Aplikasi, 20, 23, 26, (2018)

11. Undang-Undang Republik Indonesian No.6 Tahun 2014 Tentang Desa.

12. M. Saleh Lahade, Realisasi Pembangunan Masyarakat Desa Moderen (a special speech delivered at the PERMESTAS Congress, 4 (1957)

13. Panitia Pusat Kongres Bhineka Tunggal Ika, Sekitar Pelaksanaan Proklamasi 2 Maret 1957 dan Program Perdjoangan Semesta, in the collection of M. Saleh Lahade Archives No.19, the South Sulawesi Provincial Library and Archives Board, (1957). 